Article

\title{
Entry into and Completion of Vocational Baccalaureate School in Switzerland: Do Differences in Regional Admission Regulations Matter?
}

\author{
Miriam Hänni *, Irene Kriesi and Jörg Neumann
}

Citation: Hänni, M.; Kriesi, I.;

Neumann, J. Entry into and

Completion of Vocational

Baccalaureate School in Switzerland:

Do Differences in Regional

Admission Regulations Matter? Educ

Sci. 2022, 12, 188. https://doi.org/

10.3390/educsci12030188

Academic Editor: James Albright

Received: 26 September 2021

Accepted: 18 February 2022

Published: 8 March 2022

Publisher's Note: MDPI stays neutral with regard to jurisdictional claims in published maps and institutional affiliations.

Copyright: (c) 2022 by the authors. Licensee MDPI, Basel, Switzerland. This article is an open access article distributed under the terms and conditions of the Creative Commons Attribution (CC BY) license (https:/ / creativecommons.org/licenses/by/ $4.0 /)$.
Swiss Federal University for Vocational Education and Training, 3052 Zollikofen, Switzerland; irene.kriesi@ehb.swiss (I.K.); joerg.neumann@ehb.swiss (J.N.)

* Correspondence: miriam.haenni@ehb.swiss

\begin{abstract}
Upper secondary education in Switzerland is divided into a general and a vocational path. Approximately two thirds of adolescents attend the vocational path. The initial vocational education and training (IVET) can be combined with a federal vocational baccalaureate (FVB), which enables graduates to enter universities of applied sciences. The proportion of FVB holders varies considerably between Swiss regions. We study how admission regulations affect regional entry and graduation rates and how they interact with individual characteristics. We use longitudinal register data from the Federal Statistical Office to study individuals' chances of pursuing and obtaining a vocational baccalaureate in combination with data about cantonal admission criteria to vocational baccalaureate schools. We find that higher admission barriers reduce individuals' chances of pursuing a vocational baccalaureate, particularly among apprentices with low socio-economic status and those who pursue an FVB after their VET diploma. Against our expectations, high admission barriers are associated not only with lower entry rates but also with lower graduation rates.
\end{abstract}

Keywords: federal vocational baccalaureate; opportunity structures; admission regulations; graduation rates; regional variation

\section{Introduction}

Switzerland's educational system is strongly tracked and federally organized at the level of 26 cantons. This gives the cantons substantial leeway in educational provision and admission regulations [1-3]. In all cantons, the upper secondary level is divided into a general and a vocational path. The latter is chosen by approximately two thirds of adolescents, who attend initial vocational education and training (IVET). IVET includes company-based dual ( 90\%) and school-based ( 10\%) programmes. Most of the 250 IVET programmes are company-based and combine work at a firm with one or two days per week at a vocational school. IVET programmes last between two (federal VET certificate) and three to four years (federal VET diploma) and differ in their academic requirements. On finishing an IVET programme, IVET learners receive nationally recognized, standardized, and occupation-specific credentials [4,5]. Currently, about a quarter of learners combine IVET with a federal vocational baccalaureate (FVB), which provides additional general education and enables diploma holders to enter universities of applied sciences [6]. The FVB may thus help to increase the proportion of tertiary-educated employees in Switzerland and thus reduce skill shortages [7].

The vocational baccalaureate was introduced in 1994 and offers five profiles: technology, architecture and life sciences (TALS), business and services (BS), design and arts (ARTS), health and social occupations (HESO), and nature, landscape, and food (NLF). A vocational baccalaureate can be obtained in two ways: it can be completed either during IVET (FVB1) or after obtaining an IVET diploma (FVB2). Entering FVB1 school is contingent on a training contract. Entering FVB2 school after completion of IVET is contingent on 
holding a VET diploma [8]. Both options have advantages and disadvantages. A major advantage of the FVB1 is that it is completed in parallel to the IVET diploma and does not prolong time spent in education. However, achieving an FVB1 increases apprentices workload considerably and is thus very demanding. In addition, apprentices who wish to pursue an FVB1 need the support and permission of their training company, because they spend more time at vocational school and less time working in the training company. Acquiring an FVB2 makes fewer demands on time management, because the IVET diploma and the FVB take place separately. Furthermore, the FVB2 does not require the support of the training company or employer. However, it prolongs the study time by one year if studied full time or two years part time and consequently increases educational costs for individual students [9]. Currently, about half of the FVBs earned are FVB1 and the other half FVB2. Between two thirds (FVB1) and four fifths (FVB2) of students graduate [9].

Students who wish to pursue an FVB1 or FVB2 must fulfil formal admission criteria, which differ between cantons (see Sections 1.2 and 2.1.2) and the two FVB types. Moreover, the proportion of IVET learners and FVB holders varies considerably between cantons. To the best of our knowledge, the extent to which different admission criteria influence the individual probability of entering or completing FVB school and how admission regulations interact with individual and other regional characteristics have not been investigated. Admission regulations are likely to affect entry to school directly. They may also influence successful completion. In this contribution, we therefore investigate whether admission regulations affect both the transition to and successful completion of a vocational baccalaureate and whether this potential effect differs between social groups.

Whether institutional arrangements, such as admission regulations, influence the probability of entering and completing vocational baccalaureate school is relevant from a social inequality perspective as well as from an education policy perspective; the FVB is the "royal road" to universities of applied sciences for IVET graduates and therefore highly relevant for individual educational attainment. If educational opportunities and attainment depend on the canton of residence rather than students' personal ability or achievement, it is a social inequality issue. In addition, strengthening the vocational baccalaureate and thus increasing the higher education quota to address skill shortages is one of the main goals of education policy [9]. While we still lack empirical evidence about the actual role of admission regulations and its consequences for students' probability of pursuing an FVB, anecdotal evidence suggests that admission criteria do indeed matter: the canton of Zurich abolished its mandatory entrance exam for the FVB2 in 2020 in response to the COVID-19 crisis. As a result, the number of students increased considerably. To date, no evidence has emerged that the higher entry rate has increased the dropout quota [10].

We use longitudinal register data from the Federal Statistical Office to study individual chances of pursuing and obtaining a vocational baccalaureate. We combine the register data with indicators of cantonal admission criteria to FVB schools. We find that higher entry barriers negatively affect young people's chances of entering and successfully completing a vocational baccalaureate. The negative effect of high admission barriers on entry is stronger for students with low socio-economic status (SES) than for high-SES students.

\subsection{Previous Research}

Entry to FVB school is regulated at the cantonal level, leading to admission regulations that differ greatly between cantons. To the best of our knowledge, no studies explicitly address the consequences of different admission criteria for regional variations in entry into and graduation from FVB school (but see Kost 2017 for arguments about the effect of admission barriers) [7]. However, we know from previous research that educational attainment depends on regional and occupation-specific supply and opportunity structures as well as on individual factors.

Firstly, and closely related to the question of admission regulations, regional specificities in the value assigned to education pathways may explain educational attainment. Hägi [11] uses three cantonal case studies to argue that graduation rates from FVB schools 
depend, inter alia, on different education values. Likewise, Baeriswyl et al. [12] assign regional differences in quotas to historical differences in education preferences. In Frenchand Italian-speaking cantons, general education and academic pathways are favoured over vocational education, whereas in German-speaking regions vocational education is more highly valued [12]. Educational values matter, Hägi claims, because cantons with a rather elitist understanding and meritocratic concept of education may introduce more restrictive entry barriers than cantons with a more collective education perspective, where the civic idea of broad educational inclusion is highly valued [11]. There is as yet no nationwide empirical evidence to substantiate this explanation for the FVB. Admission regulations for the general baccalaureate are understood to be one of the main causes of variations between cantons in quotas [13,14] (also see Hafner et al. in this special issue [2]). For instance, Buchmann et al. show that the probability of entering a general baccalaureate school is lower in cantons with mandatory entrance exams [4].

Secondly, research comparing education pathways has underlined the importance of the regional supply of education programmes. For instance, Glauser and Becker [15] examined regional differences in educational attainment within Switzerland and found that living in areas with more extensive regional opportunity structures, such as adequate regional supply of general education programmes and favourable local labour market conditions, increases the probability of attending general education vs. IVET. In a similar vein, Sixt $[16,17]$ and Spiess and Wrohlich [18] show that the likelihood of pursuing a particular education pathway in Germany decreases with increasing spatial distance from the institution. Focusing on local labour market characteristics, Hartung et al. [19] found that adolescents in German regions with higher unemployment rates have higher educational and occupational aspirations. Weßling et al. [20] show that the local unemployment rate in Germany is negatively correlated with opportunities to enter vocational education.

Thirdly, Trede et al. [9] have shown that FVB entry and graduation rates differ substantially between occupations. Such occupational differences in FVB quotas may be related to the composition of apprentices in different occupations. Apprentices may vary in their academic achievement, social origin, gender, and canton of residence. Furthermore, we know that training companies serve as important gatekeepers to earning an FVB1. To begin an FVB1, apprentices need the support and consent of their training company. Not all training companies are equally likely to encourage their apprentices to pursue an FVB, mainly because apprentices then spend additional days in school [9].

Research into individual-level determinants of educational aspirations has shown that the early tracking in Switzerland and the early decision for or against IVET lead to strong segregation according to social background and gender $[4,21,22]$. To some extent, the FVB is considered a remedy against this social selectivity [23,24]. Schumann [25] reports that students from lower socio-economic backgrounds are more likely to pursue a vocational baccalaureate than a general one, even when reading skills are comparable. By contrast, several studies indicate that IVET learners from higher-SES families and without a migration background (except from northern European origin) have a higher probability of obtaining an FVB, even when controlling for academic performance and an occupation's academic requirement profile $[24,26,27]$. The FVB is chosen more often by male than female IVET learners $[23,24]$, which compensates for young men's underrepresentation in general baccalaureate school [23].

Studies examining the successful completion of a chosen education pathway can be divided into those focusing on school dropout and those on IVET-specific premature training contract terminations. Most research on school dropout has focused on the role of individual psychological factors. Volition, the perceived locus of control, self-efficacy, and individuals' persistence play a crucial role in the completion probability [28-30]. In addition, the literature on intended and actual school dropout has identified several psychological and behavioural risk factors, such as stress and pessimism, lacking motivation and engagement, aspirations and academic ability, low social support and lacking social networks, low social, economic, and cultural capital, and negative life events [31-33]. 
Furthermore, information deficits at the time of educational decisions have been found to be important, especially for completion of post-compulsory programmes [33].

Because the FVB1 is linked to a training contract, dropping out of FVB school may be caused by the premature termination of the training contract. Although it is possible for students to drop out of FVB1 school and to continue their apprenticeship, those who drop out of IVET prematurely usually also drop out of FVB1 school, unless they seamlessly continue their training in another company in the same or a very similar training occupation. IVET research on the premature termination of training contracts distinguishes between factors related to the student or to the company. For example, training contracts may be terminated when students are dissatisfied with the company or the work they undertake or when they do not receive sufficient guidance from workplace trainers or have conflicts with them. Conversely, companies may perceive apprentices as a bad fit or are dissatisfied with their performance and eventually dissolve their contracts [34,35].

\subsection{The Role of Admission Regulations for Entry to and Completion of Vocational Baccalaureate School: Theoretical Considerations}

Admission regulations to FVB school differ vastly between cantons and range from mandatory entrance exams, grade averages, and teacher recommendations to the passing of a preparatory course and admission interviews with the FVB school. We add to this literature by examining whether institutional admission regulation affect individuals' chances of pursuing and obtaining an FVB and how they interact with individual characteristics. Admission regulations are important means of educational governance. They set standards and define the criteria and mechanisms that restrict or legitimate individuals' access to education and educational titles [36,37]. Admission regulations can be conceptualized as opportunity structures that provide the cognitive and moral basis and the boundaries of individual agency $[38,39]$. Individual educational decisions are thus the result of interdependencies between opportunity structures and individual characteristics [31,32]. In countries such as Switzerland, where admission regulations to FVB school differ between cantons, individuals' geographical location may therefore be relevant to their educational options, decisions, and outcomes [39].

To theorize the relationship between institutional admission regulations and educational outcomes, we distinguish between institutional and discursive opportunity structures $[40,41]$. Institutional opportunity structures are the organizational structures and institutionalized rules of the educational system, both of which are guided by performance criteria. These include institutionalized assessment routines, such as entry exams, admission interviews, and preparatory courses as well as such formal criteria as actual test results, teacher recommendations, and grades. Drawing on Meyer and Rowan's [42] neo-institutional theory, Hasse [43] terms these institutional opportunity structures "formal accounts." They embody collective cultural principles that justify and legitimize decision processes and actions. Formal gatekeepers such as teachers, examiners, and training companies (see $[44,45])$ monitor compliance with rules and regulations and verify that formal admission criteria are met by those who gain access to educational settings [41].

Discursive opportunity structures are shared cultural notions and practices: "collective accounts" [43] that guide the interpretation of roles, situations, and experiences. They shape individual perceptions, including the perception and assessment of admission regulations, and thus constrain or promote potential modes of action [40]. Students with mediocre school grades, for example, may not even consider FVB school or abandon their original aspirations because they perceive it as inaccessible due to its entrance regulations. Likewise, the perception of costs and risks associated with formal admission criteria impact the probability of entering FVB school. In addition, discursive opportunity structures may shape the decision-making processes and selection procedures of gatekeepers such as teachers and vocational trainers.

Admission regulations within an educational system incorporate both types of opportunity structures, or "accounts." Consequently, educational decisions and transition 
processes depend on the interplay between institutional and discursive opportunities and individual agency $[41,43]$. For learners, admission regulations may function as objective institutional barriers because they may not meet the formal admission criteria to FVB school. Furthermore, the discursive notions and practices embedded in certain admission regulations may pose subjective barriers to learners related to psychological factors, such as exam anxiety, persistency, motivation, and feelings of entitlement [28]. The perception of these barriers may depend on an individual's social, economic, and cultural capital [31,46], leading to variation between social groups in the monetary and nonmonetary costs and benefits associated with entry into FVB school [47-49]. Depending on the configuration of these constraints and resources, specific admission regulations may pose different hurdles for apprentices.

Cantonal admission regulations to FVB school are accompanied by different modes of performance assessment and benchmarks and by different gatekeepers. They also differ in the accompanying discursive practices that encourage or discourage prospective students to pursue an FVB. Cantonal admission regulations thus differ in their rigor. We therefore assume that the chance of entering FVB school depends on the type of admission regulation and the gatekeepers involved in the process.

We argue that mandatory admission exams constitute institutional and discursive opportunities that pose the most rigorous entry barriers to FVB school [4,13]. They place high strains on students with exam anxiety and often require private tutoring to prepare for the test [50]. This raises the perceived psychological hurdles associated with entering FVB school and increases the importance of sufficient economic capital to pay for such courses. Moreover, mandatory entrance exams demand specific and intense preparation of the exam content, yet success is uncertain due to the high competitiveness of the exams, thus raising the objective barriers to FVB school. Hence, we expect mandatory entrance exams to lower the chances of students entering FVB school. This may be particularly true for low-SES students. The benefits of higher education and thus the motivation to overcome high barriers are greater for high-SES students because they and their parents want to avoid status loss, and educational values are class related [50-52]. High-SES parents may also be more able to pay for private tutoring and more likely to possess the cultural capital to support their children in preparing for the exam without taking a course $[46,50]$.

In some cantons, students need a teacher's recommendation to enter FVB school. We expect teacher recommendation to be a lower hurdle than mandatory entrance exams but a higher hurdle than grade averages alone, because it installs another institutional gatekeeper, namely the teacher's personal view of students' future potential [43]. In addition, discursive opportunities, such as cultural capital, are important for this type of regulation. Parents with substantial cultural capital are familiar with the education system and may more easily persuade teachers to reconsider their grading and to value softer aspects such as potential in their recommendations or threaten to take legal or administrative action $[22,50,53]$. The literature also shows that teachers are more likely to recommend students from high-SES families for baccalaureate school [54]. High-SES students may thus have an advantage if access to FVB school depends on teacher recommendation.

In other cantons, specific school grade averages suffice to gain access to FVB school. We expect this to be one of the lower institutional hurdles because the entry decision is based on school achievement over a longer period, usually one semester, and potentially less subjective than teacher recommendations and less vulnerable to the exertion of influence by parents or students [55]. Furthermore, achieving the necessary grades and the concomitant mastery constitute a discursive resource because it is likely to send a strong psychological signal, increasing students' self-efficacy and motivation to strive for an FVB [56,57].

In some cantons, the passing of a preparatory course or an entrance interview with the school determines access to FVB school. These two types of admission regulations add new gatekeepers while neutralizing others such as teachers. Nevertheless, we expect these two types of admission regulation to present the lowest institutional and discursive hurdles: they focus mainly on individual motivation, which remains unhampered by 
looming and costly entry exams or upper secondary teachers' evaluations and potentially biased perceptions.

From these considerations, we postulate the following hypotheses:

Hypothesis 1 (H1a). The probability of entering FVB school differs depending on cantonal admission regulations.

Hypothesis 1 (H1b). Admission regulations that pose higher admission barriers are associated with lower chances of entering FVB school. We expect the following sequence of association: mandatory entrance exams $>$ teacher recommendation $>$ grade averages (>entrance interview or preparatory course).

Hypothesis 1 (H1c). The negative effect of high admission barriers is weaker for high-SES students.

Admission to FVB1 school is contingent on the support and consent of the training company [9]. Cantonal admission regulations mainly come into play if learners have the support of their training company to pursue an FVB1. The training company thus acts as an important formal gatekeeper. It installs an additional and crucial institutional barrier to FVB1 because some training companies bar their apprentices from pursuing an FVB due to the additional days that they spend in FVB school [9]. This may neutralize the significance of institutional cantonal admission regulations. We therefore expect admission regulations to be more significant for entry to FVB school after than during IVET (H2).

Hypothesis 2 (H2). The effect of admission regulation is stronger for entry to FVB2 than FVB1.

Finally, we postulate an indirect effect of admission regulations on the probability of successful graduation because they affect who enters FVB school. The average cognitive ability of students entering baccalaureate school may be correlated with the institutional and discursive opportunity structures associated with the various admission barriers. Assuming that student abilities are equally distributed between cantons (but see Bolli et al. [58] who found that school achievement differs between language regions), student achievement in FVB school should be related to admission criteria, with students more successful in cantons with stricter and thus more selective admission regulations [13] and lower baccalaureate quotas [14]. In addition, the psychological and behavioural characteristics of students in FVB school may differ depending on the type of admission regulations. High entrance barriers, such as mandatory exams, require high motivation, engagement, and persistence. These characteristics are also essential for the successful completion of an education programme [31]. Therefore, students who pursue an FVB despite high entrance barriers may have particularly favourable personal resources, such as high levels of motivation, persistence, and self-efficacy [28,29]. In addition, the type of admission regulations may influence the extent of information deficits [33] among FVB learners. Information deficits may be higher in cantons with admission regulations that allow for less restricted entry to FVB school, such as through grade averages and teacher recommendations exams, than in cantons where an additional effort is needed, such as a mandatory entrance exam. In sum, we therefore expect entrance barriers to affect success rates among FVB learners ( $\mathrm{H} 3 \mathrm{a}$ ), with higher hurdles associated with higher chances of successful completion (H3b). As for entry to FVB school, the effect may be stronger for the FVB2 because the completion of the FVB1 also depends on training conditions, including the continuing support of the training company $(\mathrm{H} 3 \mathrm{c})$.

Hypothesis 3 (H3a). The chances of successfully completing FVB school vary depending on the type of admission regulation.

Hypothesis $3 \mathbf{( H 3 b )}$. We expect that admission regulations that pose higher admission barriers are associated with higher chances of successful completion of FVB school. We assume the following 
sequence of association: mandatory entrance exams $>$ teacher recommendation $>$ grade averages (>entrance interview or preparatory course).

Hypothesis 3 (H3c). The effect of admission barriers is stronger for the completion of the FVB2 than FVB1.

\section{Data and Methods}

\subsection{Data and Sample Selection}

We use longitudinal register data on education from the Federal Statistical Office to study the individual probability to pursue and obtain an FVB. Register data have several advantages over survey data: (i) register data are available for all individuals and not only a representative sample of the population and (ii) thus reduce the problem of nonresponses often prevalent in survey data; (iii) information is based on objective criteria and therefore not affected by response bias. On the downside, register data do not provide any information on individuals' decision-making process and include less micro-level characteristics than the available survey data. The dataset contains complete information about education careers for all individuals enrolled in education in Switzerland since 2012. In addition to education programmes, the data contain information about several individual characteristics, including gender, citizenship, and place of residence. Information on socioeconomic status (SES) is only available for $12 \%$ of the individuals in our sample, because it is derived from the Swiss structural survey. SES is therefore only available for the part of our sample who were also part of the Swiss structural survey.

We use the cohort of individuals who completed compulsory school in 2012 in Switzerland and entered a regular three- or four-year upper secondary IVET programme within two years (i.e., until summer 2014; $N=44,238$ ). Using the cohort of school graduates of 2012 allows us to investigate the longest possible time series. We exclude individuals enrolled in a specialized school with a commercial profile (Handelsmittelschule) because the vast majority of these complete an FVB that is integrated into the syllabus. Furthermore, we exclude individuals pursuing the FVB in a private school without subsidies because students in private schools are often exempt from cantonal admission requirements. We also exclude individuals who left Switzerland before or during upper secondary education and individuals who did not belong to the permanent resident population of Switzerland. Information about graduation from education programmes is available until 2019 and about entry to programmes until 2018. We thus lack information on entry and completion of some FVB2 students with a longer gap between graduation from compulsory school and entry into apprenticeship. For example, we have no information about entry into FVB2 for students who graduated from compulsory school in 2012, started a four-year apprenticeship in 2014, and (potentially) enrolled in FVB2 school in 2019. Comparing our data to graduation data from the FSO, we estimate that we lack information about FVB2 entrance and completion for a negligible $2 \%$ of our population. We combine the register data with indicators of cantonal admission criteria to FVB schools (see Section 2.1.2).

\subsubsection{Dependent Variable: Entry and Completion of an FVB}

Our dependent variable measures whether an individual pursues and completes an FVB1 or FVB2. For the FVB1, we code all individuals who have participated in an FVB course during their VET diploma as having pursued FVB1 school (entry =1). Those who successfully completed their FVB1 until 2019 are coded as having graduated from FVB1 school (successful graduation =1). Entry and completion of the FVB2 is coded analogously; apprentices who already obtained an FVB1 are excluded. Figure 1 below illustrates the variance in FVB1 (left) and FVB2 (right) graduation rates between Swiss cantons. The share of IVET graduates who complete FVB1 school is highest in the cantons of Friburg, Ticino, Basle-Country, and Zug and for the FVB2 in the cantons of Berne and Schaffhouse. 


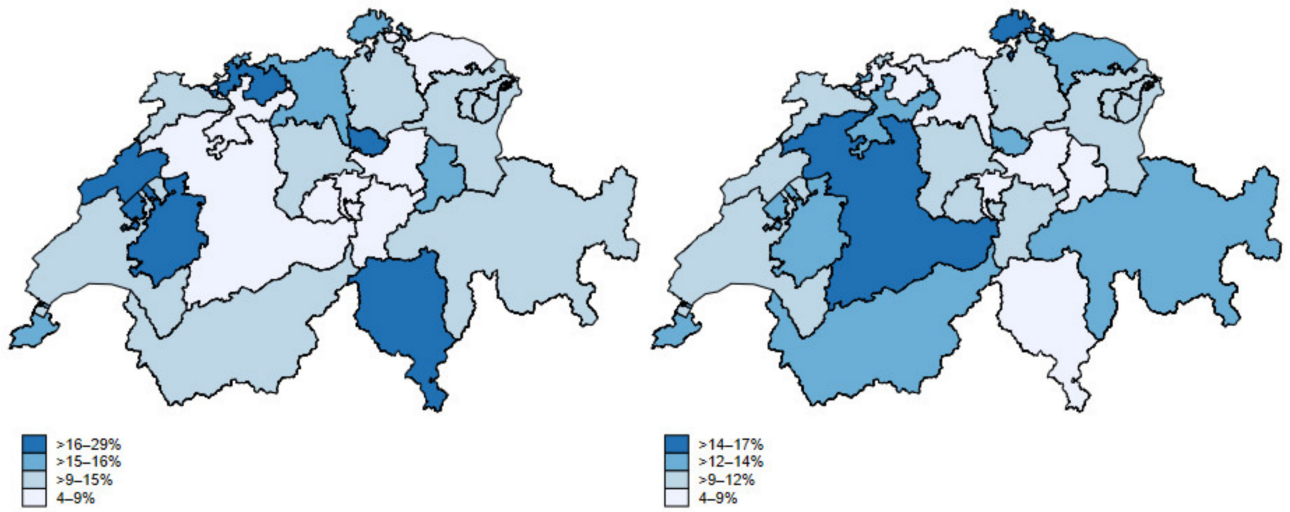

Figure 1. Proportion of IVET graduates (\%) who hold an FVB1 (left) or FVB2 (right).

\subsubsection{Explanatory Variable: Admission Regulation}

Our main explanatory variables are cantonal admission regulations to FVB school during and after vocational education and training. Information on admission regulations stems from the cantonal ordinances of FVB. We collapse the various admission regulations into three categories for the FVB1 and six categories for the FVB2. Entry requirements for the FVB1 include (i) mandatory entrance exams, (ii) grade averages (or entrance exam if average is not achieved), and (iii) teacher recommendations (or entrance exam if recommendation is not granted). Entry requirements for the FVB2 comprise (1) mandatory entrance exams, (2) a combination of grade averages and mandatory entrance exams, (3) grade averages, (4) teacher recommendations, (5) passing of a preparatory course, and (6) mandatory admission interview. Students in Categories 3-5 can take an entrance exam if they do not fulfil the corresponding entry criteria. Categories 1-2 and 3-4 were collapsed for the analysis due to a limited number of cases in these categories.

Some cantons do not have an FVB school and send their students to neighbouring cantons. Some of these cantons specify their own rules for admission to neighbouring FVB schools, and in others the rules of the neighbouring canton apply. Entry requirements have been coded accordingly. For students who enter an FVB school in another canton than their own despite the availability of a school in their canton, according to law, the rules of their canton of residence apply. (Furthermore, when admission regulations differ between profiles, we code the most widely applicable rule per canton. Entry to the business track of the FVB2 is possible without an examination for apprentices of commercial training if they fulfil a certain grade average. Because this applies to all cantons, we ignore this specificity and treat it as a constant.) To test for the interaction between SES and admission regulations (H1c), we use a dummy variable that indicates whether admission without a mandatory entrance exam is possible (mandatory entrance exam $=0$ ). A simplified overview of our coding is presented in Table 1 below (see Table S1 in the Supplementary Materials for more detailed information). 
Table 1. Coding of cantonal admission regulations into FVB1 and FVB2 schools ${ }^{a}$.

\begin{tabular}{|c|c|c|}
\hline & Entry Requirements FVB1 & Entry Requirements FVB2 \\
\hline Mandatory entrance exam & $\begin{array}{c}(\mathrm{AI})^{\mathrm{b}}, \mathrm{AR}, \mathrm{GL}, \mathrm{GR}, \mathrm{SH}, \mathrm{SZ}, \\
\text { SG, TG, ZH }\end{array}$ & $\begin{array}{l}(\mathrm{AI})^{\mathrm{b}},(\mathrm{AR})^{\mathrm{b}}, \mathrm{AG}, \mathrm{GE}, \mathrm{GR}^{\mathrm{c}}, \\
\mathrm{LU}, \mathrm{SZ}, \mathrm{SG}, \mathrm{UR}, \mathrm{VD}, \mathrm{ZG}, \mathrm{ZH}\end{array}$ \\
\hline Grade average & $\begin{array}{c}\text { AG, BS, BL, FR, GE, JU d , LU, } \\
\text { NE, NW, OW e , SO, TI, UR, } \\
\text { VD, VS }\end{array}$ & \\
\hline Teacher recommendation & $\mathrm{BE}, \mathrm{ZG}$ & \\
\hline $\begin{array}{l}\text { Grade average and/or teacher } \\
\text { recommendation }\end{array}$ & & $\begin{array}{c}\mathrm{BS}, \mathrm{BL}, \mathrm{GL}, \mathrm{JU}^{\mathrm{d}}, \mathrm{NW}^{\mathrm{e}}, \mathrm{OW}, \\
\mathrm{TG}, \mathrm{VS}\end{array}$ \\
\hline Preparatory course & & $\mathrm{BE}, \mathrm{FR}, \mathrm{NE}, \mathrm{SO}$ \\
\hline Admission interview & & $\mathrm{SH}, \mathrm{TI}$ \\
\hline \multicolumn{3}{|c|}{$\begin{array}{l}\text { Notes: }{ }^{a} \text { AG-Argovia; AR-Appenzell Outer-Rhodes; AI-Appenzell Inner-Rhodes; BS-Basle-City; BL- } \\
\text { Basle-Country; BE-Berne; FR-Friburg; GE-Geneva; GL-Glarus; GR-Grisons; JU-Jura; LU-Lucerne } \\
\text { NE-Neuchâtel; NW-Nidwald; OW-Obwald; SZ-Schwyz; SH-Schaffhouse; SO-Soleure; SG-St. Gall } \\
\text { TI-Ticino; TG-Thurgovia; UR-Uri; VD-Vaud; VS-Valais; ZG-Zug; ZH-Zurich. }{ }^{b} \text { Appenzell Inner-Rhodes } \\
\text { (FVB1 and 2) and Appenzell Outer-Rhodes (FVB2) do not specify admission regulations or offer FVB training } \\
\text { Most of their students go to Appenzell Outer-Rhodes or St. Gall for the FVB1 and St. Gall or Zurich for the FVB2 } \\
\text { Since we eventually code these cantons into the same category, mandatory entrance exam, this poses no problem } \\
\text { for the analyses. }{ }^{\mathrm{c}} \text { Entry requirements for profile HESO also differ. }{ }^{\mathrm{d}} \text { Canton of Jura is excluded from the analyses } \\
\text { because information on education careers is incomplete for our cohort. }{ }^{\text {e }} \text { Despite not having an FVB1 school, the } \\
\text { canton specifies admission criteria for its students. For more details, see Table S1 in Supplementary Materials. }\end{array}$} \\
\hline
\end{tabular}

\subsubsection{Control Variables}

We follow the literature discussed above to control for several individual and contextual characteristics that may affect individuals' chances of pursuing and completing an FVB. At the individual level, we control for an individual's citizenship (Swiss = 1), gender (female $=1$ ), the school track in lower secondary education (track with advanced requirements $=1$ ), age at the beginning of IVET, and for the family's socio-economic status (at least one parent with tertiary education $=1$ ) for a representative subset of individuals. In the analysis on the completion of FVB1, we also control whether individuals prematurely terminated their initial IVET programme during the period of observation. We do not exclude premature contract terminations from the analysis because the data show that the majority of learners with a premature contract termination resume their training shortly afterwards with another training company (see also [59]).

At the contextual level, we include information about the cantonal proportion of general baccalaureate learners in general and specialized middle schools for the same cohort that we use in our analysis. It serves as a proxy for the value of general education. We also include the intellectual requirement profile of individual training occupations (see [60]) to control for the higher FVB rate in academically more demanding programs [9]. Training occupations are rated in 21 skill domains in the areas of mathematics, language, foreign language, and natural sciences on a scale from 0 to 100 . We use the average value across all areas and skill domains in the analysis. Missing values $(n=4514,10 \%$ of the total observations) are linearly imputed with information on requirement profiles by Stalder [61].

\subsection{Method}

We proceed in two steps. First, we estimate the probability that an individual enters FVB school as a function of cantonal entry requirements and control variables. We provide clustered standard errors at the level of cantons to account for potential heterogeneity between cantons. We run the analyses separately for FVB1 and FVB2. To estimate the probability of entry to FVB1, we run logistic regressions. Entry to FVB2 school is contingent on not having completed an FVB1 during IVET training. To account for this selection into "treatment" and due to the nonlinearity of the dependent variable, we use the probit specification of the Heckman selection models (Heckprobit) [62]. The Heckman model introduces a selection equation to capture the effect of selection into treatment (i.e., completion of 
FVB1 school) on the main equation. The selection equation includes the same explanatory variables as the main equation plus an additional instrumental variable that is theoretically expected to affect the dependent variable of the selection equation (completion of FVB1 school) but not the main outcome (entry into FVB2 school) [63]. We use the termination of the training contract as an instrument to explain completion of FVB1 school. We argue that individuals who experience a premature contract termination are usually also forced to leave FVB school because attendance of the latter depends on a training contract with a firm willing to support FVB school.

Second, we examine the individual probability of successfully completing FVB school. Successful completion is contingent on entry into FVB school. Again, we make use of Heckprobit models to account for this selection into treatment. We use the cantonal quota of the general baccalaureate as an instrument to explain entry into FVB1 school and the urbanity of a student's municipality as an instrument to explain entry into FVB2 school. We see the general baccalaureate quota as a proxy for the value of general education. We expect that more students begin an FVB1 in cantons where general education is more highly valued, but graduation rates should be unaffected by this. We use urbanity as a proxy for FVB demand in the labour market. The demand for higher education, including FVB2 graduates, is likely higher in more urban areas with larger tertiary sectors but again theoretically unrelated to FVB completion. From an empirical point of view, the general baccalaureate quota performs best, but all instruments are significantly correlated with the stage one outcome.

We run our models stepwise. After a general model that only includes admission regulations and our main control variables (Models 1 and 5), we add the general baccalaureate quota as a contextual control variable on the level of cantons (Models 2 and 6), as well as SES (Models 3 and 7) and an interaction thereof (Model 4). Because we use census data for all students completing compulsory school in 2012 and continuing with IVET within two years of graduation, we present average marginal effects of our estimates and thus focus on effect sizes rather than significance levels of coefficients, which are less relevant in this context. Regression coefficients are presented in the Supplementary Materials in Tables S2 and S3.

\section{Results}

\subsection{Entry into Vocational Baccalaureate School}

Overall, 17\% of IVET learners in our cohort combine their training with an FVB1; $12 \%$ (or 14\% of those not holding an FVB1) begin an FVB2 after earning their VET diploma. Determinants of entry into FVB school are presented in Table 2. Models 1-4 present determinants for entry into FVB1, models 5-7 for entry into FVB2.

The chance that IVET learners enter FVB1 school in cantons where access is regulated by grade averages is five percentage points higher than in cantons with mandatory entrance exams (reference group; Model 1). Individuals in cantons where a teacher recommendation is required are one percentage point less likely to enter FVB school than learners in cantons with mandatory entrance exams. A comparison between cantons with teacher recommendations and cantons with grade averages reveals that individuals in cantons with grade averages have the highest chance of entering FVB school. All else being equal (i.e., holding the other covariates constant at their mean or mode), our models predict that $15.9 \%$ of IVET learners pursue an FVB in cantons where grade averages suffice to enter FVB1 school. In cantons with teacher recommendations $(9.6 \%)$ or mandatory entrance exams $(10.6 \%)$, the chance is much lower. That said, we must take into account that the effects of admission regulations are rather unstable: for example, when controlling for cantonal variations in the general baccalaureate quota (Model 2), the effect of grade averages disappears. The reason is that entry requirements to the FVB1 and the proportion of general baccalaureate learners are highly correlated $(\mathrm{r}=0.53)$. This supports the theoretical assumption that educational outcomes depend on interdependencies between collective and formal accounts or opportunity structures. Cantons in which general education is highly valued have not 
only a high proportion of general baccalaureate students but also lower barriers to FVB1 school, which encourage IVET learners to pursue an FVB. In line with this interpretation, we found the highest proportion of general baccalaureate students in cantons with grade averages as an entry requirement into FVB1 school (mean of $30 \%$ in cantons with grade averages vs. $20 \%$ for mandatory entrance exams).

Table 2. Individual and contextual determinants for entry into FVB1- and FVB2-school (average marginal effects displayed, for regression coefficients see Table S2).

\begin{tabular}{|c|c|c|c|c|c|c|c|}
\hline & \multicolumn{4}{|c|}{ FVB1 Entry } & \multicolumn{3}{|c|}{ FVB2 Entry } \\
\hline & (1) & (2) & (3) & (4) & (5) & (6) & (7) \\
\hline \multicolumn{8}{|l|}{$\begin{array}{l}\text { Entry requirements } F V B, \\
\quad \text { Ref }=\text { mandatory entrance exam }\end{array}$} \\
\hline Grade average & $\begin{array}{l}0.05^{+} \\
(0.02)\end{array}$ & $\begin{array}{c}0.00 \\
(0.02)\end{array}$ & $\begin{array}{l}0.06^{* * *} \\
(0.01)\end{array}$ & & & & \\
\hline Teacher recommendation & $\begin{array}{c}-0.01 \\
(0.01)\end{array}$ & $\begin{aligned}-0.02 * \\
(0.01)\end{aligned}$ & $\begin{array}{c}-0.02 \\
(0.01)\end{array}$ & & & & \\
\hline Admission interview & & & & & $\begin{array}{l}0.10^{* * *} \\
(0.02)\end{array}$ & $\begin{array}{l}0.09 * * * \\
(0.01)\end{array}$ & $\begin{array}{l}0.08^{+} \\
(0.04)\end{array}$ \\
\hline Preparatory course & & & & & $\begin{array}{l}0.05^{* *} \\
(0.02)\end{array}$ & $\begin{array}{l}0.05^{* * *} \\
(0.00)\end{array}$ & $\begin{array}{l}0.05^{* * *} \\
(0.02)\end{array}$ \\
\hline $\begin{array}{l}\text { Grade average/Teacher } \\
\text { Recommendation }\end{array}$ & & & & & $\begin{array}{c}0.02 \\
(0.02)\end{array}$ & $\begin{array}{l}0.02 * * * \\
(0.01)\end{array}$ & $\begin{array}{c}0.01 \\
(0.02)\end{array}$ \\
\hline $\begin{array}{l}\text { Admission without entry exam } \\
\text { (Dummy) }\end{array}$ & & & & $\begin{array}{l}0.04^{* * *} \\
(0.01)\end{array}$ & & & \\
\hline \multicolumn{8}{|l|}{ Control variables } \\
\hline Women & $\begin{array}{l}-0.03^{* * *} \\
(0.01)\end{array}$ & $\begin{array}{l}-0.02^{* * *} \\
(0.01)\end{array}$ & $\begin{array}{c}-0.03 * * \\
(0.01)\end{array}$ & $\begin{array}{c}-0.03^{* *} \\
(0.01)\end{array}$ & $\begin{array}{c}0.00 \\
(0.01)\end{array}$ & $\begin{array}{c}0.00 \\
(0.00)\end{array}$ & $\begin{array}{c}0.00 \\
(0.01)\end{array}$ \\
\hline Swiss & $\begin{array}{c}0.01 \\
(0.01)\end{array}$ & $\begin{array}{l}0.02 * \\
(0.01)\end{array}$ & $\begin{array}{c}0.01 \\
(0.02)\end{array}$ & $\begin{array}{l}-0.00 \\
(0.02)\end{array}$ & $\begin{array}{r}-0.00 \\
(0.01)\end{array}$ & $\begin{array}{r}-0.00 \\
(0.01)\end{array}$ & $\begin{array}{c}-0.06^{*} \\
(0.02)\end{array}$ \\
\hline Age at IVET beginning & $\begin{array}{l}-0.05^{* * *} \\
(0.01)\end{array}$ & $\begin{array}{l}-0.04^{* * *} \\
(0.01)\end{array}$ & $\begin{array}{l}-0.05^{* * * *} \\
(0.01)\end{array}$ & $\begin{array}{l}-0.05^{* * *} \\
(0.01)\end{array}$ & $\begin{array}{l}-0.03 * * \\
(0.01)\end{array}$ & $\begin{array}{l}-0.03 * * * \\
(0.00)\end{array}$ & $\begin{array}{l}-0.02 * \\
(0.01)\end{array}$ \\
\hline $\begin{array}{l}\text { High social status/Tertiary } \\
\text { educated parents }\end{array}$ & & & $\begin{array}{l}0.05^{* * *} \\
(0.01)\end{array}$ & $\begin{array}{l}0.05^{* * *} \\
(0.01)\end{array}$ & & & $\begin{array}{l}0.06^{* * *} \\
(0.01)\end{array}$ \\
\hline $\begin{array}{l}\text { School track with additional requirements } \\
\text { in lower secondary education }\end{array}$ & $\begin{array}{l}0.13^{* * *} \\
(0.02)\end{array}$ & $\begin{array}{l}0.14^{* * *} \\
(0.01)\end{array}$ & $\begin{array}{l}0.14^{* * *} \\
(0.01)\end{array}$ & $\begin{array}{l}0.14^{* * *} \\
(0.01)\end{array}$ & $\begin{array}{l}0.14^{* * *} \\
(0.03)\end{array}$ & $\begin{array}{l}0.13^{* * *} \\
(0.01)\end{array}$ & $\begin{array}{l}0.12 * * * \\
(0.01)\end{array}$ \\
\hline $\begin{array}{l}\text { Academic requirements of } \\
\text { training occupation }\end{array}$ & $\begin{array}{l}0.011^{* * *} \\
(0.00)\end{array}$ & $\begin{array}{l}0.01^{* * *} \\
(0.00)\end{array}$ & $\begin{array}{l}0.02^{* * *} \\
(0.00)\end{array}$ & $\begin{array}{l}0.02 * * * \\
(0.00)\end{array}$ & $\begin{array}{l}0.01^{* * *} \\
(0.00)\end{array}$ & $\begin{array}{l}0.01^{* * * *} \\
(0.00)\end{array}$ & $\begin{array}{l}0.01^{* * *} \\
(0.00)\end{array}$ \\
\hline General baccelaureate (quota) & & $\begin{array}{l}0.39^{* * *} \\
(0.12)\end{array}$ & & & & $\begin{array}{l}0.04^{+} \\
(0.02)\end{array}$ & \\
\hline $\begin{array}{l}\text { Admission without entry exam * } \\
\text { High social status * }\end{array}$ & & & & $\begin{array}{c}-0.03 \\
(0.02)\end{array}$ & & & \\
\hline Observations & 40,228 & 40,228 & 4654 & 4616 & 35,209 & 35,209 & 4567 \\
\hline
\end{tabular}

Notes: Standard errors (calculated by delta method) in parentheses: ${ }^{+} p<0.10,{ }^{*} p<0.05,{ }^{* *} p<0.01,{ }^{* * *} p<0.001$ Models 3, 4, and 7 include weights to adjust for the fact that information on SES is only available for a subset of the sample. * The value for the interaction effect is calculated as the difference in the AME of admission without entry exam for high-SES and low-SES students.

The effect of admission regulations is stronger and more stable for entry into FVB2 school (Model 5). In comparison to individuals living in cantons with mandatory admission exams, individuals in cantons where an admission interview or the passing of a preparatory course are required have a much higher chance of beginning an FVB2 $(+10$ and +5 percentage points, respectively). The effect of grade averages or teacher recommendations is rather small and comparable to that of mandatory entrance exams (+2 percentage points). In line with hypothesis 1a, mandatory entrance exams thus pose the highest hurdle and admission interviews and preparatory courses the lowest hurdles. In line with hypothesis 2, we found a stronger and less volatile effect of entry requirements for entry into FVB2 school than FVB1 school. We explain this difference with the varying role of training companies: whereas FVB1 learners need the explicit support of their training company if they wish to pursue an FVB, the decisions of FVB2 learners are only contingent on passing the entry requirements. The role of training companies may thus weaken the effect of entry requirements.

However, the effect of admission criteria is not entirely homogenous across different groups of students (H1c). In Model 4, we tested whether the probability of entering 
FVB school differs between socio-economic groups. Individuals with at least one tertiary educated parent are five percentage points more likely to begin with an FVB1 than those whose parents have no tertiary education. For the FVB1, the negative interaction between SES and admission without entrance exams means that entrance exams reduce the entry probability to FVB1 school more for low-SES apprentices than for high-SES apprentices (H1c). This may be explained by differences in both types of opportunity structures. LowSES apprentices may face more difficulties in paying for private tuition to prepare for the exam. They are also likely to be hampered by less favourable discursive opportunities, such as lower social support, self-efficacy beliefs, and aspirations, resulting in different cost-benefit calculations. Furthermore, we cannot exclude the possibility that differences that we could not control for in cognitive abilities between social groups play a role. For the FVB2, the interaction cannot be calculated due to the limited number of observations.

Our analysis of individual and contextual control variables reveals that the effect of gender is close to zero for entry into FVB2, but negative for entry into FVB1: women have a three percentage points lower probability of entering FVB1 school. The effect of Swiss citizenship is unstable and differs between models. Older students are less likely to pursue an FVB (approximately -5 percentage points per year for FVB1; -3 percentage points per year for FVB2). The age effect is likely to reflect uncontrolled characteristics of older students that are detrimental for educational attainment. IVET learners who are older than 16 when they enter vocational education and training have either been retained during compulsory school, been unable to secure an apprenticeship, or dropped out of a previous upper secondary course. Previous research has shown that such educational irregularities negatively affect educational attainment [64]. Students who have completed a school track with advanced requirements have a 13 percentage points higher probability of beginning an FVB than students in other school tracks. Among the contextual control variables, the effect of academic requirements for the training occupation is most notable. Students in training occupations with higher academic requirements are more likely to enter FVB school (+1 percentage point per scale point). Our data do not allow us to distinguish whether this effect is driven by students' intellectual capabilities or companies' occupation-specific recruiting practices. The proportion of general baccalaureate learners is more strongly related to the chances of pursuing an FVB1 than an FVB2.

\subsection{Graduation from Vocational Baccalaureate School}

In the cohort analysed, 26\% of FVB1 learners and 13\% of FVB2 learners did not successfully graduate from FVB school. In the following paragraphs, we examine how entry requirements and individual determinants affect the probability of successful completion (see Table 3). As in Table 2, we first present results for graduation from FVB1 (Models 1-4) before evaluating determinants of successful graduation from FVB2 (model 5). Models 1 and 5 include our general models, Model 2 adds a measure for whether students have terminated their training contract during IVET training, Model 3 includes SES, and Model 4 an interaction between SES and admission regulation. As mentioned above and due to data restrictions, models with SES can only be estimated for graduation from FVB1. 
Table 3. Individual and contextual determinants for the successful completion of FVB1 and FVB2 (Heck-probit models with average marginal effects; for regression coefficients see Table S3).

\begin{tabular}{|c|c|c|c|c|c|}
\hline \multirow[t]{2}{*}{ Step 2} & \multicolumn{4}{|c|}{ FVB1 Completion } & \multirow{2}{*}{$\begin{array}{l}\text { FVB2 Completion } \\
\text { (5) }\end{array}$} \\
\hline & (1) & (2) & (3) & (4) & \\
\hline \multicolumn{6}{|l|}{$\begin{array}{l}\text { Entry requirements } F V B \text {, } \\
\text { Ref }=\text { mandatory entrance exam }\end{array}$} \\
\hline Grade average & $\begin{array}{l}0.05^{*} \\
(0.02)\end{array}$ & $\begin{array}{c}0.04 \\
(0.03)\end{array}$ & $\begin{array}{l}0.05^{*} \\
(0.02)\end{array}$ & & \\
\hline Teacher recommendation & $\begin{array}{l}0.04 \\
(0.03)\end{array}$ & $\begin{array}{c}0.03 \\
(0.03)\end{array}$ & $\begin{array}{l}0.00 \\
(0.03)\end{array}$ & & \\
\hline Admission interview & & & & & $\begin{array}{l}0.11^{* * *} \\
(0.03)\end{array}$ \\
\hline Preparatory course & & & & & $\begin{array}{l}0.07^{*} \\
(0.03)\end{array}$ \\
\hline Grade average/Teacher recommendation & & & & & $\begin{array}{l}0.04^{+} \\
(0.02)\end{array}$ \\
\hline Admission without entry exam (Dummy) & & & & $\begin{array}{l}0.05^{*} \\
(0.02)\end{array}$ & \\
\hline \multicolumn{6}{|l|}{ Control variables } \\
\hline Women & $\begin{array}{c}0.07^{*} \\
(0.03)\end{array}$ & $\begin{array}{l}0.06^{+} \\
(0.04)\end{array}$ & $\begin{array}{c}0.03 \\
(0.03)\end{array}$ & $\begin{array}{c}0.05 \\
(0.03)\end{array}$ & $\begin{array}{c}0.02 \\
(0.02)\end{array}$ \\
\hline Swiss & $\begin{array}{l}0.05^{*} \\
(0.02)\end{array}$ & $\begin{array}{l}0.06^{* *} \\
(0.02)\end{array}$ & $\begin{array}{l}0.09 * \\
(0.04)\end{array}$ & $\begin{array}{l}0.10^{*} \\
(0.05)\end{array}$ & $\begin{array}{c}0.02 \\
(0.02)\end{array}$ \\
\hline Age at IVET beginning & $\begin{array}{l}-0.06^{* * *} \\
(0.01)\end{array}$ & $\begin{array}{l}-0.06^{* * *} \\
(0.02)\end{array}$ & $\begin{array}{l}-0.05^{* * *} \\
(0.01)\end{array}$ & $\begin{array}{l}-0.05^{* *} \\
(0.02)\end{array}$ & $\begin{array}{c}-0.05^{+} \\
(0.02)\end{array}$ \\
\hline High social status/Tertiary educated parents & & & $\begin{array}{l}0.05^{*} \\
(0.02)\end{array}$ & $\begin{array}{l}0.05^{*} \\
(0.02)\end{array}$ & \\
\hline $\begin{array}{l}\text { School track with additional requirements } \\
\text { in lower secondary education }\end{array}$ & $\begin{array}{l}0.30^{* * * *} \\
(0.06)\end{array}$ & $\begin{array}{l}0.26^{* *} \\
(0.08)\end{array}$ & $\begin{array}{l}0.17^{* *} \\
(0.06)\end{array}$ & $\begin{array}{l}0.20^{* * * *} \\
(0.06)\end{array}$ & $\begin{array}{l}0.18^{+} \\
(0.11)\end{array}$ \\
\hline Academic requirements of training occupation & $\begin{array}{l}0.01^{* * *} \\
(0.00)\end{array}$ & $\begin{array}{l}0.01 * * * \\
(0.00)\end{array}$ & $\begin{array}{l}0.01^{* * *} \\
(0.00)\end{array}$ & $\begin{array}{l}0.01^{* * *} \\
(0.00)\end{array}$ & $\begin{array}{l}0.01 * * * \\
(0.00)\end{array}$ \\
\hline Dropout (termination of training contract) & & $\begin{array}{l}-0.16^{* *} \\
(0.06)\end{array}$ & $\begin{array}{c}-0.11^{*} \\
(0.06)\end{array}$ & $\begin{array}{c}-0.14^{*} \\
(0.06)\end{array}$ & \\
\hline $\begin{array}{l}\text { Admission without entry exam * } \\
\text { High social status * }\end{array}$ & & & & $\begin{aligned}-0.02 \\
(0.05)\end{aligned}$ & \\
\hline Observations (first step) & 40,228 & 39,753 & 4588 & 4550 & 34,318 \\
\hline
\end{tabular}

Notes: Clustered standard errors (canton) in parentheses: ${ }^{+} p<0.10,{ }^{*} p<0.05,{ }^{* *} p<0.01,{ }^{* * *} p<0.001$. Models 3 and 4 include weights to adjust for the fact that information on SES is only available for a subset of the sample. * The value for the interaction effect is calculated as the difference in the AME of admission without entry exam for high-SES and low-SES students.

We expected that admission regulations based on rigorous performance criteria, such as entry exams, are a better predictor of future success than grade averages or teacher recommendations $[12,13]$ (H3a). However, we found no support for this hypothesis. To the contrary, students living in cantons with mandatory admission exams are considerably less likely to graduate successfully from FVB school than students living in cantons with other entry requirements (see Table 3 ). All else being equal, students have the best chances of successfully completing their FVB1 in cantons where grade averages suffice to enter FVB school (53.4\%) and the lowest chances in cantons with mandatory entrance exams $(46.7 \%)$. As for FVB2 school, students in cantons with admission interviews are most likely $(42.3 \%)$ and students in cantons with mandatory entrance exams are least likely (24.4\%) to successfully graduate. In contrast to entry into FVB school, the effect of admission regulations on the successful graduation from school is not moderated by SES (see Model 4. Please note that the predicted probabilities of successfully completing an FVB are lower than the actual completion rates. The reason is that predicted probabilities are calculated for an "average person", whereas the descriptive results represent the actual completion rate.

These unexpected findings may be due to several reasons. First, students in cantons with mandatory entrance exams often use private tutoring based on "teaching to the test" methods to prepare for the entrance exam. Although this type of preparation helps to pass entry exams, it does not ensure that students have enough resources to keep up with the teaching pace at FVB school. Second, cantonal differences in the discursive and institutional opportunity structures of FVB school may play a role. If cantons have low 
entry barriers because they value general education highly, they may also have a more favourable school climate or a better support system that reduces IVET learners' dropouts. Third, some studies find that success at one level of school is a good predictor of success at the next level. In line with our results, this might mean that grade averages are the better predictor of individual performance and thus success than competitive entrance exams [12]. Without data on the performance, reasoning, and decision-making processes of IVET learners who do not successfully complete the FVB, we cannot test either of these explanations empirically.

Our results for the control variables indicate that although women are less likely to enter FVB school, they are more likely than men to successfully complete it $(+7$ percentage points for FVB1, +2 percentage points for FVB2). We found a similar pattern for apprentices' citizenship: despite the absence of a stable citizenship effect on entry into FVB school, Swiss nationals seem a bit more likely to graduate from FVB school than non-Swiss ( +5 percentage points for FVB1, +2 percentage points for FVB2). In addition, our results indicate that IVET learners with at least one tertiary-educated parent are more likely to successfully complete FVB school (+5 percentage points). One of the most important explanatory variables is the track of lower secondary school. Students who completed a track with advanced requirements in lower secondary education have a much higher probability $(+30$ percentage points for FVB1, +18 percentage points for FVB2) of successfully completing FVB school than those who attended a track with basic requirements. The effect is smaller but still sizeable for the completion of FVB2, meaning that the type of lower secondary education influences students' educational achievement even beyond compulsory school. Students who quit their apprenticeship contract during training are less likely to complete the FVB1 ( -16 percentage points), as are older students ( -6 percentage points per year for FVB1; -5 percentage points per year for FVB2). At the contextual level, our study reveals that IVET learners in training occupations with higher academic requirements are more likely to complete their FVB (+1 percentage point per scale point). Comparing the success rate of students in the training occupation with the lowest academic requirement profile in the sample (logistician) and students with the highest academic requirement profile (physics lab technician), the success rates differ by more than 60 (for FVB1) and 50 (for FVB2) percentage points, respectively.

We conducted several robustness tests (see Tables S4 and S5 in the Supplementary Materials). Results are stable across all model specifications.

First, we replicated our models with fixed effects for occupation fields to control for heterogenous effects across occupation fields. In these models, we excluded our measure for the academic requirement of training occupations because it is highly correlated with occupation fields. Our main findings remained stable in this alternative model specification (see Models 1-2 and 4-5 in Table S5).

Second, we calculated the main models for entry and completion of FVB2 school without the canton of Grisons, because admission regulations to the FVB2 in the canton of Grisons vary more strongly across profiles than in other cantons. Results do not differ substantially if we exclude Grisons (see Models 7 and 8 in Table S5).

Third, we estimated the models including a Heckman correction for selection bias with standard logistic regressions with clustered standard errors because the athrho coefficients in Tables S2 and S3 do not provide evidence of a large selection effect. The main effects of admission regulations are comparable to those under the Heckprobit specification (see Table S4 and Models 3 and 6 in Table S5).

\section{Discussion and Conclusions}

This paper contributes to the literature on regional differences in educational attainment. We focused on regional variation of entry into and graduation from vocational baccalaureate (FVB) school. Going beyond previous research, which has explained such variation primarily with regional labour market variations or cultural values, e.g., [11,19,21], our paper sheds light on the role of admission regulations to FVB school. We conceptu- 
alized admission regulations as institutional and discursive opportunity structures that shape formal entry criteria and selection practices as well as students' perceptions of an education's accessibility. These constitute formal and discursive hurdles, which differ between cantons in their rigour.

In line with our hypotheses, we find that cantonal admission regulations are more important for entry into FVB2 than FVB1. The likely reason is that the transition to FVB school during IVET involves an additional formal gatekeeper; it depends not only on cantonal admission regulations but also on the support and permission of the training firm to pursue an FVB1. Our findings thus point to the crucial role of training companies as gatekeepers and support the assumption that educational decisions are also the result of interdependencies and interactions between various elements of opportunity structures (see [41]). However, we are not aware of any studies that have analysed these interdependences empirically, particularly regarding the role of training firms. Further studies are thus needed to investigate the criteria that firms apply in their recruitment and their decision to support or hinder apprentices in pursuing the FVB1.

Our findings highlight the fact that mandatory entrance exams pose the highest hurdles by lowering the chances of entering both types of federal FVB school the most. The negative effect of mandatory entrance exams is particularly strong for entry into FVB2 and for IVET learners with a low SES. Firstly, this supports the assumption that formal access regulations accompany discursive collective accounts or opportunities that encourage or discourage certain groups of students, for example, those with low academic self-efficacy beliefs. Secondly, it points to the relationship between institutional opportunity structures and individual resources. The preparation for mandatory entrance exams is facilitated by private tutoring and thus by economic resources. Not all students have the economic means to pay for such courses, which may reduce the chances of low-SES students' entering school tracks with such access regulation.

Cantonal admission rules legitimate students' access to FVB school by supposedly selecting students based on academic merit. However, the finding that mandatory entrance exams not only reduce individuals' chances of entering FVB school but are also a poor predictor for successful completion challenges this formal account. Admission regulations based on personal interviews with prospective students or preparatory courses have been shown to be more efficient in selecting successful FVB2 candidates. These regulations are likely to take a wider range of formal criteria into account when selecting students, including motivation or suitable learning strategies. They may also include discursive practices that discourage students who are more likely to fail due to a lack of resources such as motivation, support, or academic abilities.

From a theoretical point of view, our results support the assumption that admission regulations constitute institutional and discursive opportunity structures or "accounts", to use Meyer and Rowan's [45] terminology, that do indeed matter for education careers by shaping access criteria, gatekeepers' access decisions, and young people's educational decisions. This has important implications for mechanisms of social inequality. Firstly, an individual's geographical location and place of residence have an impact on access to education and thus on individual educational attainment-an aspect that has hitherto been neglected in theories of educational attainment. Secondly, the interaction effect between SES and mandatory entrance exams implies that mechanisms of social inequality may be moderated by students' place of residence. Regional opportunity structures may therefore exacerbate or ameliorate mechanisms of social inequality arising from young people's socio-economic background.

Our study also has some shortcomings. First, we lack individual-level data on ability, motivation, and the resources that are likely to impact educational aspirations and decisions. The advantages of administrative data, such as full samples and objective information, come at the cost of limited individual-level information. Consequently, we are not able to empirically distinguish between the institutional and discursive aspects of cantonal admission regulations. Although our theoretical assumptions are in line with the results and 
highly plausible, future studies using survey or experimental data are needed to substantiate our theoretical interpretation of the findings and investigate the empirical relevance of individual competencies, motivation, perceptions, and resources-including cost-benefit calculations-related to admission regulations. In addition to the lack of empirical evidence on the micro-mechanisms that explain the relationship between admission regulations and the probability of entering FVB school, we know even less about the mechanisms that link admission regulations to the successful graduation from education programmes. We have very little evidence about whether admission regulations affect the composition of students in particular programmes (but see [13]), or how they interact with factors such as school cultures and schools' support systems.

Our study also has policy implications. If mandatory entrance exams reduce the chances of entering FVB school without increasing the probability of successful completion, they counteract the aim of increasing FVB rates to meet employers' demand for highly skilled workers. Recent experiences in the canton of Zurich, where admission exams were abolished in 2020 and 2021, indicate that this strategy can increase entry rates without affecting success rates. In the cantons of Argovia and St. Gall, similar propositions are currently debated in their legislatures. Thus, in contrast to the general baccalaureate, where official or unofficial maximum quotas are applied in many cantons (see Hafner et al. in this special issue [2]), there seems to be more political leeway to increase the number of places in FVB schools. Finally, the more pronounced effect of admission regulations on the FVB2 raises questions about the role of training companies and their support for the FVB1. Abolishing high entry barriers may not suffice to increase the FVB1 quota. In addition, political stakeholders should ensure that the FVB1 remains or becomes an attractive option for both apprentices and training companies [9].

Supplementary Materials: The following are available online at https:/ /www.mdpi.com/article/ 10.3390/educsci12030188/s1, Table S1: Entry requirements into FVB1 and FVB2 schools in Swiss cantons; Table S2: Individual and contextual determinants for entry into FVB1- and FVB2-school (regression results); Table S3: Individual and contextual determinants for the successful completion of FVB1 and FVB2 (Heckprobit models); Table S4: Individual and contextual determinants for entry into FVB2-school (logistic regression models); Table S5: Entry into and completion of FVB school: robustness tests.

Author Contributions: Conceptualization, M.H., I.K. and J.N.; methodology, M.H. and I.K.; software, M.H. and J.N.; validation, M.H. and J.N.; formal analysis, M.H.; writing—original draft preparation, M.H. and I.K; writing—review and editing, M.H. and I.K.; supervision, I.K.; project administration, I.K. All authors have read and agreed to the published version of the manuscript.

Funding: This research received no external funding.

Institutional Review Board Statement: Not applicable.

Informed Consent Statement: Not applicable.

Data Availability Statement: Restrictions apply to the availability of these data. Data was obtained from the Federal Statistical Office and are available from the author with the permission of the Federal Statistical Office.

Acknowledgments: We thank Miriam Grønning, Seraina Leumann, and Lydia Schmutz for their support in the data collection on admission regulations. We thank participants of the "Regionale Differenzen in den Bildungsangeboten, Zulassungsbedingungen und Bildungsverläufen in der Schweiz: Ursprünge, Governance und Folgen" panel at the Congress of the Swiss Sociological Association 2021 for their constructive feedback and valuable suggestions on an early version of this study.

Conflicts of Interest: The authors declare no conflict of interest.

\section{References}

1. Hega, G.M. Federalism, Subsidiarity and Education Policy in Switzerland. Reg. Fed. Stud. 2000, 10, 1-35. [CrossRef] 
2. Hafner, S.; Esposito, R.S.; Leemann, R.J. Transition to Long-Term Baccalaureate School in Switzerland: Governance, Tensions, and Justifications. Educ. Sci. 2022, 12, 93. [CrossRef]

3. Leemann, R.J.; Pfeifer Brändli, A.; Imdorf, C. Access to Baccalaureate School in Switzerland-Regional Variances of Institutional Conditions and its Consequences for Educational Inequalities. Educ. Sci. 2022, 12, 20.

4. Buchmann, M.; Kriesi, I.; Koomen, M.; Imdorf, C.; Basler, A. Differentiation in secondary education and inequality in educational opportunities: The case of Switzerland. In Models of Secondary Education and Social Inequality-An International Comparison; Blossfeld, H.-P., Buchholz, S., Skopek, J., Triventi, M., Eds.; Edward Elgar Publishing: Cheltenham, UK; Northampton, MA, USA, 2016; pp. 111-128.

5. Grønning, M.; Kriesi, I.; Sacchi, S. Income during the early career: Do institutional characteristics of training occupations matter? Res. Soc. Stratif. Mobil. 2020, 67, 100495. [CrossRef]

6. Bundesamt für Statistik (BFS). Maturitätsquote-Daten des Indikators. Available online: https://www.bfs.admin.ch/bfs/de/ home/statistiken/bildung-wissenschaft/bildungsindikatoren/themen/bildungserfolg/maturitaetsquote.assetdetail.14715808 .html (accessed on 2 February 2021).

7. Kost, J.; Lüthi, F.; Fischer, J. Die Berufsmaturitätsquote zwischen Volatilität und Stabilität—Eine bildungspolitische Herausforderung. SGAB Newsl. 2017. Available online: https:/ /sgab-srfp.ch/die-berufsmaturitaetsquote-zwischen-volatilitaet-undstabilitaet-eine-bildungspolitische-herausforderung/ (accessed on 2 February 2021).

8. Wettstein, E.; Schmid, E.; Gonon, P. Swiss Vocational and Professional Education and Training (VPET). Forms, System, Stakeholders; Hep Verlag AG: Bern, Switzerland, 2017.

9. Trede, I.; Hänni, M.; Leumann, S.; Neumann, J.; Gehret, A.; Schweri, J.; Kriesi, I. Berufsmaturität. Bildungsverläufe, Herausforderungen und Potenziale; Eidgenössisches Hochschulinstitut für Berufsbildung: Zollikofen, Switzerland, 2020.

10. Donzé, R. Matura nach der Lehre erleichtern. NZZ am Sonntag. Available online: https://magazin.nzz.ch/schweiz/schulenbesser-durchmischen-ld.1608953 (accessed on 1 April 2021).

11. Hägi, L. Disparate Entwicklungen der schweizerischen Berufsmaturität-Zur Wertigkeit eines beruflichen Bildungsabschlusses in verschiedenen Kantonen. In Bildung und Konventionen. Die "Economie des conventions" in der Bildungsforschung; Imdorf, C., Leemann, R.J., Gonon, P., Eds.; Springer: Wiesbaden, Germany, 2019; pp. 341-369.

12. Baeriswyl, F.; Trautwein, U.; Wandeler, C.; Lüdtke, O. Wie gut prognostizieren subjektive Lehrerempfehlungen und schulische Testleistungen beim Übertritt die Mathematik und Deutschleistung in der Sekundarstufe I? In Bildungsentscheidungen; Springer: Wiesbaden, Germany, 2010; pp. 352-372.

13. Brüggenbrock, C.; Eberle, F.; Oelkers, J. Die jüngeren Entwicklungen des Gymnasiums und der Matura in der Schweiz. In Abitur und Matura im Wandel; Kramer, J.N., Neumann, M., Trautwein, U., Eds.; Springer: Wiesbaden, Germany, 2016; pp. 59-80.

14. SKBF-CSRE. Swiss Education Report 2018; Schweizerische Koordinationsstelle für Bildungsforschung: Aarau, Switzerland, 2018.

15. Glauser, D.; Becker, R. VET or general education? Effects of regional opportunity structures on educational attainment in German-speaking Switzerland. Empir. Res. Vocat. Educ. Train. 2016, 8, 8. [CrossRef]

16. Sixt, M. Wohnort, Region und Bildungserfolg. Die strukturelle Dimension bei der Erklärung von regionaler Bildungsungleichheit. In Bildungskontexte. Strukturelle Voraussetzungen und Ursachen ungleicher Bildungschancen; Becker, R., Schulze, A., Eds.; Springer: Wiesbaden, Germany, 2013; pp. 457-481.

17. Sixt, M. Regionale Strukturen als herkunftsspezifische Determinanten von Bildungsentscheidungen. Ph.D. Thesis, Universität Kassel, Kassel, Germany, 10 February 2010.

18. Spiess, C.K.; Wrohlich, K. Does distance determine who attends a university in Germany? Econ. Educ. Rev. 2010, 29, 470-479. [CrossRef] 
19. Hartung, A.; Wessling, K.; Hillmert, S. Educational and Occupational Aspirations at the End of Secondary School: The Importance of Regional Labour-Market Conditions; GSBE Research Memoranda No. 019; Maastricht University, Graduate School of Business and Economics: Maastricht, The Netherlands, 2019. Available online: https://cris.maastrichtuniversity.nl/en/publications/ educational-and-occupational-aspirations-at-the-end-of-secondary- (accessed on 2 February 2021).

20. Weßling, K.; Hartung, A.; Hillmert, S. Spatial structure counts: The relevance of regional labour-market conditions for educational transitions to vocational training. Empir. Res. Vocat. Educ. Train. 2015, 7, 12. [CrossRef]

21. Becker, R.; Glauser, D. Vocational Education and Training, Vocational Baccalaureate or Academic High School? An Empirical Analysis of Social Selective Transitions to Upper Secondary Education in the German-Speaking Part of Switzerland. Swiss J. Sociol. 2018, 44, 9-33. [CrossRef]

22. Becker, R.; Jäpel, F.; Beck, M. Diskriminierung durch Lehrpersonen oder herkunftsbedingte Nachteile von Migranten im Deutschschweizer Schulsystem? Swiss J. Sociol. 2013, 39, 517-549.

23. Imdorf, C.; Koomen, M.; Murdoch, J.; Guégnard, C. Do Vocational Pathways Improve Higher Education Access for Women and Men from Less Privileged Social Backgrounds? A Comparison of Vocational Tracks to Higher Education in France and Switzerland. Rass. Ital. Sociol. 2017, 58, 283-314. [CrossRef]

24. Kriesi, I.; Leemann, R.J. Tertiarisierungsdruck-Herausforderungen für das Bildungssystem, den Arbeitsmarkt und das Individuum. Swiss Acad. Commun. 2020, 15, 1-52.

25. Schumann, S. Leistungs- und Herkunftseffekte beim Hochschulzugang in der Schweiz. Ein Vergleich zwischen Absolventinnen und Absolventen mit gymnasialer Maturität und mit Berufsmaturität. Z. Pädagogik 2011, 57, 246-268.

26. Jäpel, F. Die Berufsmaturität als Ausbildungsalternative. In Einflussfaktoren Individueller Bildungsentscheidungen am Übergang in die Nachobligatorische Ausbildung; Haupt: Bern, Switzerland, 2017.

27. Glauser, D. Berufsausbildung oder Allgemeinbildung. In Soziale Ungleichheiten beim Übergang in die Sekundarstufe II in der Schweiz; Springer: Wiesbaden, Germany, 2015.

28. Schlüter, C.; Fraenz, C.; Pinnow, M.; Voelkle, M.C.; Güntürkün, O.; Genç, E. Volition and academic achievement: Interindividual differences in action control mediate the effects of conscientiousness and sex on secondary school grading. Motiv. Sci. 2018, 4, 262-273. [CrossRef]

29. Wright, S.L.; Jenkins-Guarnieri, M.A.; Murdock, J.L. Career Development Among First-Year College Students. J. Career Dev. 2012, 40, 292-310. [CrossRef]

30. Heckhausen, J.; Heckhausen, H. Motivation und Handeln; Springer: Berlin/Heidelberg, Germany, 2018.

31. Samuel, R.; Burger, K. Negative life events, self-efficacy, and social support: Risk and protective factors for school dropout intentions and dropout. J. Educ. Psychol. 2020, 112, 973-986. [CrossRef]

32. De Witte, K.; Cabus, S.; Thyssen, G.; Groot, W.; van den Brink, H.M. A critical review of the literature on school dropout. Educ. Res. Rev. 2013, 10, 13-28. [CrossRef]

33. Backes-Gellner, U.; Herz, H.; Kosfeld, M.; Oswald, Y. Do preferences and biases predict life outcomes? Evidence from education and labor market entry decisions. Eur. Econ. Rev. 2021, 134, 103709. [CrossRef]

34. Stalder, B.; Schmid, E. Lehrvertragsauflösung und Ausbildungserfolg-kein Widerspruch: Wege und Umwege zum Berufsabschluss; Hep Verlag AG: Bern, Switzerland, 2016.

35. Leber, U.; Schwengler, B. Betriebliche Ausbildung in Deutschland: Unbesetzte Ausbildungsplätze und Vorzeitig Gelöste Verträge Erschweren Fachkräftesicherung; Institut für Arbeitsmarkt-und Berufsforschung: Nürnberg, Germany, 2021.

36. Fried, J. Higher education governance in Europe: Autonomy, ownership an accountability-A review of the literature. In Higher Education Governance between Demoratic Culture, Academic Aspirations and Market Forces; Kohler, J., Huber, J., Eds.; Council of Europe Publishing: Strasbourg, France, 2006; Volume 5, pp. 79-134.

37. Langer, R. Skizzen zur governanceanalytischen Theoretisierung von Bildungsungleichheit, Bildungssystem und Gesellschaft. In Handbuch Educational Governance Theorien; Langer, R., Brüsemeister, T., Eds.; Springer: Wiesbaden, Germany, 2019 ; pp. 71-97.

38. Schmid, L.; Hasse, R. Kulturelle Zurechnungen und Vokabulare der Problemkonstruktion. Soz. Probl. 2010, 21, 143-166.

39. Levy, R.; Bühlmann, F. Towards a socio-structural framework for life course analysis. Adv. Life Course Res. 2016, 30, 30-42. [CrossRef]

40. Parreira do Amaral, M.; Jornitz, S. Die Konzeptualisierung von Bildungsverläufen Jugendlicher: Eine Governance-Perspektive auf Lebenslauf. In Handbuch Educational Governance Theorien; Langer, R., Brüsemeister, T., Eds.; Springer: Wiesbaden, Germany, 2019; Volume 43, pp. 417-440.

41. Walther, A. Meritokratie, Gate-Keeper und Bildungsentscheidungen: Reproduktion von Ungleichheit durch die Herstellung von Übergängen. In Individualisierte Übergänge. Aufstiege, Abstiege und Umstiege im Bildungssystem; Thiersch, S., Silkenbeumer, M., Labede, J., Eds.; Springer: Wiesbaden, Germany, 2020; pp. 61-85.

42. Meyer, J.; Rowan, B. Institutionalized organizations: Formal structure as myth and ceremony. Am. J. Sociol. 1977, 83, 340-363. [CrossRef]

43. Hasse, R. Organisationssoziologische Bildungsanalysen. Eine Situationseinschätzung. In Die Organisation von Bildung-Soziologische Analysen zu Schule, Berufsbildung, Hochschule und Weiterbildung; Leemann, R.J., Imdorf, C., Powell, J.J.W., Eds.; Beltz: Weinheim, Germany, 2016; pp. 47-67. 
44. Scherger, S. Konzeptuelle Überlegungen zum Zusammenhang von Bildungsverläufen und -strukturen. Zeitliche (De-)Standardisierung in Bildungssystemen und soziale Ungleichheit. In (De)Standardisierung von Bildungsverläufen und -strukturen: Neue Perspektiven auf bildungsbezogene Ungleichheit; Makrinus, L., Otremba, K., Rennert, C., Stoeck, J., Eds.; Springer Fachmedien Wiesbaden GmbH: Wiesbaden, Germany, 2016; pp. 39-58.

45. Struck, O. Gatekeeping zwischen Individuum, Organisation und Institution: Zur Bedeutung und Analyse von Gatekeeping am Beispiel von Übergängen im Lebenslauf. In Institution und Lebensläufe im Wandel: Institutionelle Regulierungen von Lebensläufen; Leisering, L., Müller, R., Schumann, K.F., Eds.; Juventa: Weinheim, Germany, 2001; pp. 29-54.

46. Bourdieu, P. Ökonomisches, kulturelles, soziales Kapital. In Soziale Ungleichheiten; Kreckel, R., Ed.; Schwartz: Göttingen, Germany, 1983; pp. 183-198.

47. Heinz, W.R. Structure and agency in transition research. J. Educ. Work. 2009, 22, 391-404. [CrossRef]

48. Boudon, R. Education, Opportunity and Social Inequality: Changing Prospects in Western Society; Wiley: New York, NY, USA, 1974.

49. Becker, R. Klassenlage und Bildungsentscheidungen. Eine empirische Anwendung der Wert-Erwartungstheorie. KZfSS Kölner Z. Soziologie Soz. 2000, 52, 450-474. [CrossRef]

50. Combet, B. The Institutional Dimension of Class-based Educational Decision-making: Evidence from Regional Variation in Switzerland. Z. Für Soziologie 2019, 48, 301-320. [CrossRef]

51. Bourdieu, P.; Passeron, J.-C. Reproduction in Education, Society and Culture; Sage Publications: London, UK, 1977.

52. Breen, R.; Goldthorpe, J.H. Explaining Educational Differentials: Towards a Formal Rational Action Theory. Ration. Soc. 1997, 9 , 275-305. [CrossRef]

53. Hofstetter, D. Die Schulische Selektion als Soziale Praxis. Aushandlungen von Bildungsentscheidungen beim Übergang von der Primarschule in die Sekundarstufe I; Beltz Juventa: Weinheim, Germany, 2017.

54. Ditton, H.; Jan, K.; Schauenberg, M. Bildungsungleichheit-der Beitrag von Familie und Schule. Z. Erzieh. 2005, 8, 285-304. [CrossRef]

55. Gomolla, M. Schulische Selektion und institutionelle Diskriminierung. In Schulübergang und Selektion. ForschungsbefundePraxisbeispiele-Umsetzungsperspektiven; Neuenschwander, M.P., Grunder, H.-U., Eds.; Rüegger Verlag: Zürich, Switzerland, 2010; pp. 61-90.

56. Bandura, A. Self-Efficacy: The Exercise of Control; Freeman: New York, NY, USA, 1997.

57. Joët, G.; Usher, E.L.; Bressoux, P. Sources of self-efficacy: An investigation of elementary school students in France. J. Educ. Psychol. 2011, 103, 649-663. [CrossRef]

58. Bolli, T.; Rageth, L.; Renold, U. The Social Status of Vocational Education and Training in Switzerland. KOF Work. Pap. 2019, 451, $1-47$.

59. Bundesamt für Statistik (BFS). Bildungsverläufe auf Sekundarstufe II. Längsschnittanalysen im Bildungsbereich; BFS: Neuchâtel, Switzerland, 2018.

60. Goetze, W. Schulische Anforderungsprofile für die Berufliche Grundbildung-Informationsbulletin; Büro für Bildungsfragen: Thalwil, Switzerland, 2013.

61. Stalder, B.E. Das Intellektuelle Anforderungsniveau Beruflicher Grundbildungen in der Schweiz. Ratings der Jahre 1999-2005; Institut für Soziologie der Universität Basel: Basel, Switzerland, 2011.

62. Heckman, J.J. Sample Selection Bias as a Specification Error. Econom. J. Econom. Soc. 1979, 47, 153-161. [CrossRef]

63. Cerulli, G. Econometric Evaluation of Socio-Economic Programs. Theory and Applications; Springer: Berlin/Heidelberg, Germany, 2015.

64. Sacchi, S.; Meyer, T. Übergangslösungen beim Eintritt in die Schweizer Berufsbildung: Brückenschlag oder Sackgasse? Schweiz. Z. Für Soziologie 2016, 42, 9-39. [CrossRef] 